\title{
Critical Evaluation of the Oxygen-Enhanced Combustion in Gas Burners for Industrial Applications and Heating Systems
}

\author{
Alex A. B. Santos, ${ }^{*, a, d}$ Ednildo A. Torres ${ }^{c, d}$ and Pedro A. P. Pereira ${ }^{b, d}$ \\ ${ }^{a}$ Centro Integrado de Manufatura e Tecnologia (Cimatec, SENAI), \\ Av. Orlando Gomes no. 1845, Piatã, 41650-010 Salvador-BA, Brazil \\ ${ }^{b}$ Instituto de Química, Universidade Federal da Bahia, Rua Barão de Geremoabo s/n, \\ Campus Universitário de Ondina, 40170-115 Salvador-BA, Brazil \\ ${ }^{c}$ Escola Politécnica, Universidade Federal da Bahia, Rua Professor Aristides Novis no. 2, \\ Federação, 40210-630 Salvador-BA, Brazil \\ ${ }^{d}$ Centro Interdisciplinar de Energia e Ambiente (CIEnAm), Universidade Federal da Bahia, \\ Campus Universitário de Ondina, 40170-115 Salvador-BA, Brazil
}

\begin{abstract}
O conceito de eficiência energética em equipamentos está cada vez mais em pauta com os desdobramentos do aquecimento global e, dentre os equipamentos industriais, os queimadores possuem um dos maiores impactos nesta discussão por se tratar de um equipamento de combustão industrial. A procura por queimadores mais eficientes energeticamente é imprescindível para o adequado uso de combustíveis fósseis durante a fase de transição entre esta fonte de energia para as energias alternativas, a qual pode durar mais de cinquenta anos. O presente trabalho traz uma avaliação do uso da técnica de combustão enriquecida com oxigenio (OEC), identificando importantes pontos, especialmente na transferência de calor e na emissão de poluentes, para a aplicação desta técnica na indústria de petróleo e sua cadeia, na qual a utilização da OEC é raramente usada. Não foi identificada na literatura uma revisão crítica do uso da OEC e as implicações do seu uso na indústria de petróleo e gás.
\end{abstract}

The concept of energetic efficiency in equipments is highlighted nowadays, due to its implication with the global warming issues. Amongst industrial equipments, burners have one of the greatest impacts on this discussion, since they are large scale combustion devices. The search for more efficient burners is of paramount importance, toward a more adequate use of the fossil fuels, during the transition phase between this energy source and new alternatives, which may last more than fifty years. The present work brings an evaluation of the Oxygen Enhanced Combustion technique (OEC), identifying important issues, especially those related with the heat transfer and emission of pollutants, and discussing its application in the oil industry and its supply chain, where the OEC is barely used. As far as the authors could search in the literature, there are no published critical reviews regarding the use of OEC and its implications in the oil and gas industry.

Keywords: oxygen, combustion, oxygen enhanced combustion, industrial heating processes

\section{Introduction}

Energy efficiency control in industrial equipment has always been a relevant subject in industrial activity. Industrial burners such as boilers, gas turbines and ovens are common place. Their use is distributed in many industrial sectors, like the oil, gas, petrochemical, steel and automobile fields in particular. Another important aspect is that burning is used as

*e-mail: alex.santos@ fieb.org.br the combustion process for energy generation. According to Turns, ${ }^{1}$ approximately $89 \%$ of the used energy in the United States came from fuel combustion in 1989. In Brazil, about $84 \%$ of energy is produced by combustion sources. ${ }^{2}$

Nowadays, the production and use of oil, natural gas and alcohol in Brazil are in full expansion. The increase in the potentiality and control of industrial burners have became an important point for optimization and development of more efficient energy equipment, with less impact on the environment. 
In this context, there has been a lot of research in new methodologies and new processes of combustion control provided by the scientific community for technological development. Among researches, the industrial application of air combustion with oxygen enrichment has appeared in recent years (oxygen enhanced combustion, OEC). The recent technologies of oxygen production have enabled greater competitiveness of oxygen use for application in industrial combustion.

Baukal $\mathrm{Jr}^{3}{ }^{3}$ is the main structured reference on the OEC use. It is commented that the lowest levels of the enrichment (volumetric fractions of oxygen $\left(\mathrm{O}_{2}\right)$ in the combustion air below $30 \%$ ) are normally used in retrofit applications, in which only small modifications are necessary in the existing equipment. Moreover, expressive benefits are obtained with a significant increase in the production rate in processes of heating with low levels of enrichment. In most cases, burners can operate successfully using air of combustion air enriched with up to $28 \%$ of oxygen, without modification in the equipment.

Furthermore, Baukal $\mathrm{Jr}^{3}$ showed that many industrial heating processes can be improved by substitution of part or total of the air with oxygen of high purity. Typical applications include heating and fusing of metals, fusing of glass and calcification. In a report from Gas Research Institute, ${ }^{4}$ the applications which were identified as possible candidates for the OEC: processes which have high exhaust temperatures and low thermal efficiency, due to constraints in the heat transfer typical in such conditions; processes with loading limitations, which could benefit from an additional heat transfer, without an adverse effect on the quality of the product; processes in which exhaust compounds are both in the gas and particle phases; processes with high NOx emission rates and processes with limitations in the volume of the exhaust gases.

The present work presents the benefits and the potential problems of the OEC, making a critical evaluation of its use in heating processes. Besides, the possible applications in the oil and gas industry and its derivatives are examined.

\section{Energetic Aspects of the OEC Use}

The enrichment methods used in industrial processes in industries such as those in the glass and ceramics sectors are presented by Baukal $\mathrm{Jr}^{3}$ These are divided into four basic processes: (i) through the addition of oxygen in the airflow admitted in the burner (enrichment air, Figure 1), (ii) through the injection of $\mathrm{O}_{2}$ directly in the generated flame $\left(\mathrm{O}_{2}\right.$ lancing, Figure 2), (iii) by substituting the air with pure oxygen (oxy/fuel, Figure 3 ) and (iv) providing oxygen and air for the combustion separately, normally related to air-oxy/fuel (Figure 4).

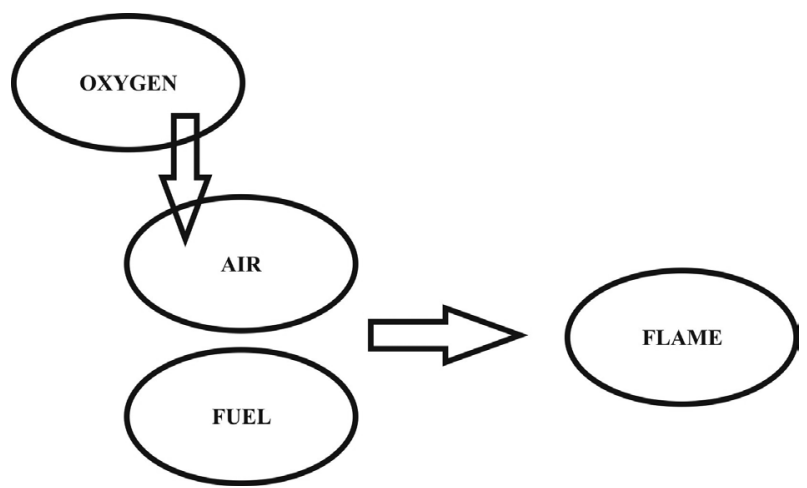

Figure 1. Enrichment methodology with $\mathrm{O}_{2}$ : air enrichment. Adapted from reference 3 .

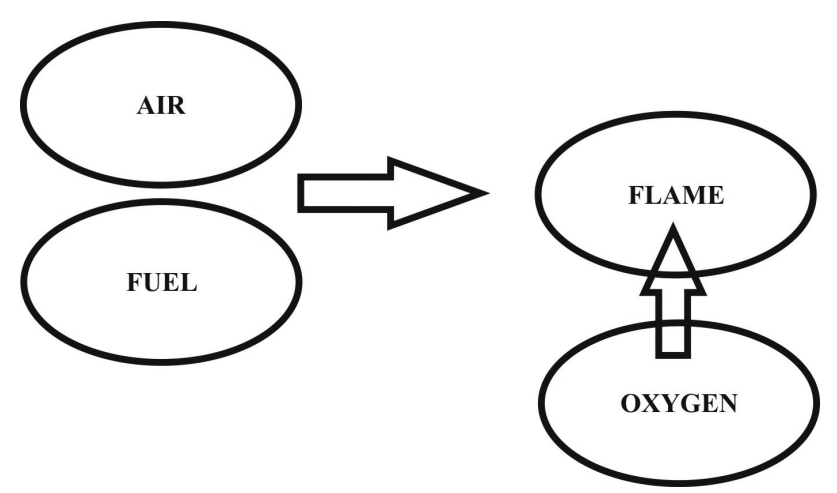

Figure 2. Enrichment methodology with $\mathrm{O}_{2}: \mathrm{O}_{2}$ lancing. Adapted from reference 3 .

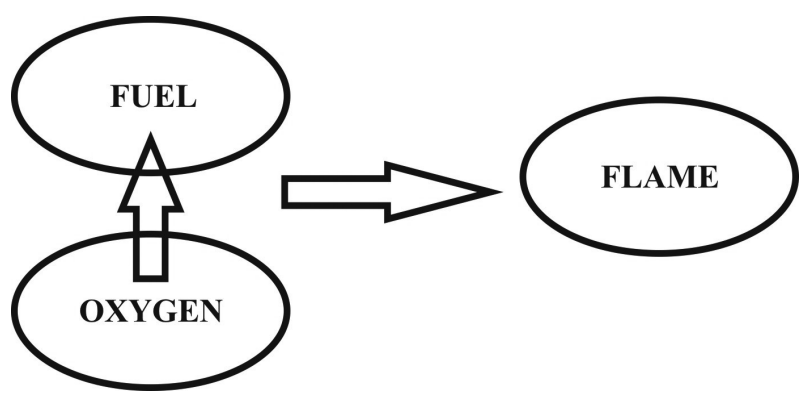

Figure 3. Enrichment methodology with $\mathrm{O}_{2}$ : oxy/fuel. Adapted from reference 3 .

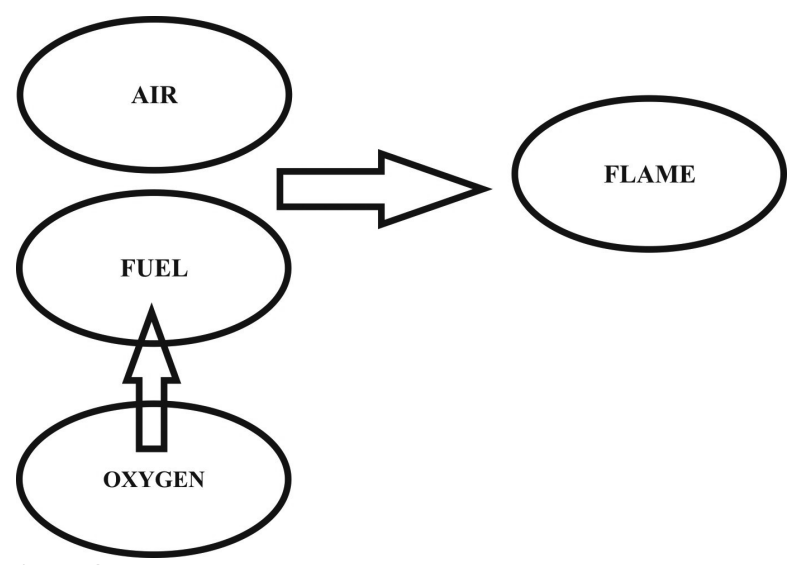

Figure 4. Enrichment methodology with $\mathrm{O}_{2}$ : air-oxy/fuel. Adapted from reference 3 . 
For the systems that operate with direct addition of oxygen in the airflow, and depending on the level of enrichment, the combustion equipment does not need to undergo significant alterations. Therefore, the molar fraction is described in equation 1 :

$\Omega=\frac{\left(\mathrm{O}_{2} \text { fraction in the oxidant volume }\right)}{\text { (total oxidant volume) }}$

In order to understand, atmospheric air possess $\Omega=0.21$ or $21 \%$. Airflow enriched with $10 \%$ of oxygen means that in this case $\Omega$ has a value of 0.31 (31\%).

In a preliminary analysis, the mechanism of airflow with oxygen enrichment (Figure 1) is presented as the more adaptable and simplest methodology for the existing systems of industrial combustion for power generation (thermoelectric) and, for low levels of enrichment, does not demand great structural changes for its implantation. However, new studies must be carried out to verify the effect of the implementation of the energy performance and the generated environmental impact with the implantation of the OEC in these systems.

Amongst the energy benefits of OEC use, we can highlight the increase of the productivity, improvement in the flame characteristics, lower volume of combustion gases, greater efficiency in the heat transfer, improvement in the product quality, reduction in the fuel consumption, raw material and costs of new equipment or the possibility of increasing existing equipment production. ${ }^{3}$

Baukal $\mathrm{Jr}^{3}{ }^{3}$ comments the increase in the productivity in heating processes where thermal radiation is the way to transfer the dominant heat. The radiation depends on the absolute temperature to fourth power order $[\mathrm{Q}=\mathrm{Q}(\mathrm{T} 4)]$. Greater the temperatures, associated with OEC, greater is the increase in the radiation of the flame, thus increasing the heat transfer. It is implemented with the OEC through the radiation and the increase of $\mathrm{CO}_{2}$ and $\mathrm{H}_{2} \mathrm{O}$ concentration in particular. These are participant species in the heat transfer through radiation, which produces high rates of raw material processing in the combustion chamber. Therefore, more raw materials can be processed in the existing system, or new proposed systems will be less able to reach the same production. Thus, less energy will be necessary to obtain the same amount of production.

Baukal $\mathrm{Jr}^{3}$ pointed out about the fuel savings by retrofitting air/fuel systems with OEC. The typical reductions are of $c a .48 \%$ based on different types of industries, except for oil and gas industry. The economic data did not identify the use of OEC in this activity.

The cost increase due to adoption of the OEC in an existing combustion system is usually lower compared to the costs associated with an expansion or a new eventual equipment acquisition to increase production.

Baukal and Gebhart ${ }^{5}$ studied the influence of the OEC in flames with natural gas. The thermal radiation was drastically implemented with the removal of the $\mathrm{N}_{2}$ from the oxidant. With the use of oxygen in substitution to air, more energy remains in the chamber for processing a determined load, instead of energy losses caused by the discarded enthalpy in the chimneys through the $\mathrm{N}_{2}$, which only absorbs energy in the combustion. With the increase in the available heat in the chamber, productivity is raised by having less energy loss through chimneys and lower fuel consumption is obtained.

Takita $^{6}$ studied, by a numerical computational model, the ignition behavior of plasma jet (PJ) in supersonic flow. The start of the PJ was made though the fuel injection downstream and upstream the jets, utilizing $\mathrm{O}_{2}, \mathrm{~N}_{2}$ and air to start the flames. The results have suggested that the $\mathrm{O}_{2}$ $\mathrm{PJ}$ and the $\mathrm{N}_{2}$ PJ have presented better performance than the air PJ, to enhance the ignition of the flames.

Murphy and Shaddix ${ }^{7}$ studied the oxygen-enhanced and the oxygen-fired pulverized coal combustion. The studies evaluated the cost reductions in the flue gas cleanup, besides the kinetics of the coal combustion process. The experimental results have demonstrated that the pulverized coal particles combustion occurs at high combustion rates, in environments with elevated oxygen concentrations, while at the same time a increasing kinetic control was also observed in these cases.

Several other papers studied energetic aspects of the OEC, not only in gaseous fuels. ${ }^{8-22} \mathrm{Cho}$ et al..$^{20}$ studied liquid fuels. Murphy and Shaddix ${ }^{7}$ and Smart et al. ${ }^{10}$ assessed coal and biomass. These studies open possibilities for using the OEC in numerous types of fuels.

As regards the economic aspect, the energy benefits bring a reduction in costs of new equipment due to greater productivity of the equipment and the improvement in the heat transfer with the OEC. If the equipment is more efficient, it requires less space, becoming more competitive than equipment using air as oxidant. The increase in the production of existing equipment is caused by the increase in productivity, as mentioned before.

Another important issue is the cost decreases, due to a reduction both in the raw materials and in the volume of the exhaust gases, since the OEC reduces the input of fuel and oxidant, compared to systems which work with air as the oxidant. This suggests a less transport of impurities to the system, reducing costs for cleaning and washing of the raw material. Another factor to be considered is the high productivity of the OEC systems, which need fewer amounts of raw material in order to produce the specified final product. 
Given these benefits, this technology could play a useful role in the oil and gas industry and its derivatives. However, the market prices of oxygen must ever be considered. To evaluate the feasibility of the OEC, some questions need to be addressed, such as: how much expenses could be increased, due to the implementation of changes in equipment for using this technology?; how far the lack of information about potential problems which can occur in systems can affect its reliability? Despite this, the OEC technology should be evaluated by this economic sector, as an alternative which brings economic and environmental savings.

As mentioned above, and the resulting greater energy efficiency, OEC should be considered by the oil and gas industries and other industrial segments as an important technological innovation to provide energy efficiency, reduce fuel consumption, and thus contribute in the reduction of emissions and global warming. The environmental aspects of OEC are presented below.

\section{Environmental Aspects of the OEC Use}

One of the main points of the environmental benefits of OEC is the reduction in the volume of exhaustion gases since enrichment with $\mathrm{O}_{2}$ basically involves nitrogen removal in the oxidant chain. Compared to systems that use atmospheric air, OEC significantly reduces the volume of exhausts to the atmosphere depending on the oxygen fraction in the oxidant used. The greater availability of oxygen in the oxidant, the lower the fuel consumption; and the combustion processes become more efficient and less polluting as a result.

Baukal Jr. ${ }^{3}$ also presents aspects concerning the emission of pollutants as follows.

\section{1. $N O_{x}$}

Baukal $\mathrm{Jr}^{3}{ }^{3}$ uses $\mathrm{NO}_{\mathrm{x}}$ to refer to the nitrogen oxides. These generally include the nitrogen monoxide (NO), also known as nitric oxide and the nitrogen dioxide $\left(\mathrm{NO}_{2}\right)$. In most heating applications with high temperatures, most of the NOx found in the exhausting gases is the NO.

$\mathrm{NO}_{\mathrm{x}}$ is toxic to humans and, depending on its concentration in the air, can cause irritation to the eyes and skin, nauseas, migraine and gradual loss of conscience. Another negative effect associated with $\mathrm{NO}_{\mathrm{x}}$ in the air is its role in the chemistry of the atmosphere. For example, the reaction of $\mathrm{NO}_{2}$ with $\mathrm{OH}$ radicals leads to the formation of nitric acid, causing acid depositions with consequent damages to trees, plants and buildings. Also, reactions of $\mathrm{NO}_{2}$ with organic compounds, such as those present in unburned fuels, in the presence of sunlight, gives rise to ozone and photochemical smog. However, the NO is, also, of paramount importance to the human physiology. Recent research results have shown how NO can regulate the mechanisms for the control of the blood pressure and act as a chemical messenger in the nervous system.

The OEC use produces contradictory effects in the formation of $\mathrm{NO}_{\mathrm{x}}$ (basically $\mathrm{NO}$ ). There are two effects that compete in the production of NO in OEC systems. As the concentration of $\mathrm{O}_{2}$ increases in the chain of the oxidant, the temperature of the flame tends to increase and these speeds up the formation of $\mathrm{NO}_{\mathrm{x}}$ caused by the exponential dependence of the thermal $\mathrm{NO}_{x}$ reactions with temperature. However, at greater levels of enrichment (above 70\%), the $\mathrm{N}_{2}$ concentration diminishes drastically and the formation of $\mathrm{NO}_{\mathrm{x}}$ falls consequently. ${ }^{3}$

The formation of $\mathrm{NO}_{\mathrm{x}}$ can also be affected by the design of burners. New research is needed to ascertain the effect caused by the configurations of burners in $\mathrm{NO}_{\mathrm{x}}$ formation.

To measure the real effect of the influence of OEC on the formation of $\mathrm{NO}_{\mathrm{x}}$ at low levels of enrichment, it is necessary to connect the effect of temperature increase to heat transmission through radiation, because, as will be described later, the formation of soot is implemented in certain regions of the flame in most cases, reducing its temperature and consequently the emission of $\mathrm{NO}_{\mathrm{x}}$. New data is required to relate the connecting process between the soot, thermal radiation and the formation of $\mathrm{NO}_{\mathrm{x}}$. This can be an important tool for the oil and gas industries to reducing of fuel consumption and the environmental impact in the global warming.

\section{2. $\mathrm{CO}$}

The formation of CO with OEC tends to reduce with the increase of the oxygen volume in the oxidant. OEC promotes a more complete burning of fuel, hindering $\mathrm{CO}$ formation. $\mathrm{CO}$ formation is chemically connected to the formation of NO. In reducing atmospheres, $\mathrm{CO}$ formation gets preference compared to the NO formation. It was not found in the literature studies on the emission of $\mathrm{CO}$ using the OEC. However, the reduction of $\mathrm{CO}$ is observed due to the increased amount of oxygen available in the region of flame oxidation.

\subsection{Volatile organic compounds (VOC)}

VOC are organic chemical compounds which have high vapor pressures, under normal atmospheric pressure and temperatures. A wide range of carbon-based molecules, 
such as lightweight aldehydes, ketones, aliphatic and aromatic hydrocarbons can be classified as VOC (e.g., benzene and formaldehyde).

It is expected that the VOC emissions go down with $\mathrm{OEC}$, as a result of the increase in the flame temperature, the lower dilution and the increase in the residence time in the combustion chamber. The efficiency of destruction and removal of VOCs increase dramatically with OEC. In the burning of municipal solid residues, VOC emissions have been reduced with use of low levels of enrichment with $\mathrm{O}_{2}$ in the combustion air, as described by Strauss et al..$^{23}$

It was not found in the literature a significant amount of studies on the emission of VOC using the OEC. This shows the need for further studies on this subject.

\section{4. $S O_{x}$}

Sulfur oxides, usually referred to as $\mathrm{SO}_{\mathrm{x}}$, are of great importance in the emissions of industrial combustion systems. According to Baukal Jr., ${ }^{3}$ the OEC use does not normally bring changes in the $\mathrm{SO}_{x}$ emissions. However, as seen previously, as the volume of exhaust gases is reduced with the OEC use, the $\mathrm{SO}_{x}$ emissions are lower compared to systems that use atmospheric air as oxidant.

\section{5. $\mathrm{CO}_{2}$}

OEC can reduce $\mathrm{CO}_{2}$ emissions significantly because of the increase of energy efficiency, which provide the same amount of energy with a lower fuel consumption. According to Farrell et al.,$^{24}$ the replacement of air burners with oxy-fuel equipment in processes of metal casting, can generate a reduction of $55 \%$ in $\mathrm{CO}_{2}$ emissions.

Reduction in $\mathrm{CO}_{2}$ emissions is an important issue to use as a base for the cost/benefit analysis of OEC implantation. Regarding the greenhouse effect, this factor must be considered as a financial and social profit. The industrial sector should include aspects of greenhouse gases reduction as benefits generated for the society, in its evaluation of financial return. This aspect is also relevant for the use of this technology in the oil and gas industries and derivatives.

\subsection{Soot}

In the OEC research, the study of soot formation is an important issue requiring specific attention, because it is both a pollutant and a media of thermal radiation.

Soot is a solid particulate material, with a carbon structure, produced in combustion. Some soot has appreciable amounts of hydrogen as well as other elements and composites, obtained from the original structure of the fuel.

According to Glassman, ${ }^{25}$ the characteristics of the produced solids in combustion differ according to the conditions of their formation. One of the most important differences is when the particle is formed in a homogeneous reaction in the vapor phase, or as a deposit on a solid surface (superficial growth), which can be located inside or close to the reaction zone.

According to Smith, ${ }^{26}$ the formation mechanisms of soot are given by the pyrolysis of the fuel or pyrolysis in the presence of an oxidant, nucleation, superficial growth, coagulation and agglomeration.

Ideally, the soot formation is desired at the beginning of the flame to implement heat transfer, through thermal radiation, and destroyed at the end of the flame, in order not to be emitted into the atmosphere.

Baukal $\mathrm{Jr}^{3}{ }^{3}$ notes that the OEC use generally reduces the emission of soot, compared soot to the burners with air. However, new designs of oxy/fuel equipment still present soot emission. This shows that there is an open field for the study of OEC in the formation of soot and it is an important factor for the implementation of energy performance of burners due to its role in thermal radiation. Brookes and $\mathrm{Moss}^{27}$ confirmed the close relationship between rates of soot production and loss of flame heat due to radiation through the study of a computational model of the production prediction of soot and thermal radiation.

Some studies of the enrichment influence through oxygen of combustion air in the formation of soot are presented below.

The direct addition of oxygen, and its effects on the soot formation, to methane diffusion flame was studied by Saito et al. ${ }^{28}$ and Gülder. ${ }^{29}$ Gülder, ${ }^{29}$ Wey et al..${ }^{30}$ Hura and Glassman, ${ }^{31}$ Du et al. ${ }^{32}$ and Leung and Lindstedt ${ }^{33}$ studied the addition to propane and butane diffusion flames. Hura and Glassman, ${ }^{31}$ Du et al. ${ }^{32}$ Leung and Lindstedt ${ }^{33}$ and Hwang et al. ${ }^{34}$ studied the addition of oxygen to ethane diffusion flames. Kent and Bastin ${ }^{35}$ studied the addition of oxygen to free turbulent diffusion acetylene flames over a wide range of velocities and nozzle sizes.

The literature about addition of oxygen to the combustion air in a burner with a parallel annular oxidizer flow includes Glassman and Yaccarino, ${ }^{36}$ Lee et al. ${ }^{37}$ Zelepouga et al.,$^{38}$ Hwang and Gore, ${ }^{39}$ Wang et al. ${ }^{40}$ and Wang et $a l .{ }^{41}$

Lee et $a l .{ }^{37}$ studied the influence of diffuse flames enrichment of methane/air through $\mathrm{O}_{2} . \mathrm{O}_{2}$ was injected in the airflow, enriching the air to 50 and $100 \%$ of $\mathrm{O}_{2}$ in volume conditions, considering the air with a mixture of $\mathrm{N}_{2}$ and $\mathrm{O}_{2}$. 
The authors verified the reduction of soot production in the two conditions of the enrichment, the $100 \%$ condition being the one that stimulated greater reduction. Zelepouga et al. ${ }^{38}$ also verified the influence of enrichment with $\mathrm{O}_{2}$ in the side of the air in diffuse laminar flames of methane. The evaluation parameter was the integrated radial concentration of the soot. The authors noticed a reduction in the formation of soot for volumetric grade of $\mathrm{O}_{2}$ in the air of 35,50 and $100 \%$. The authors had also found that soot concentration was lower for flames with greater grades of $\mathrm{O}_{2}$ because of the shorter lengths of the flame and the shorter time available for the growth of soot particles.

In some works, the variation in the $\mathrm{O}_{2}$ grade in the air was done in such a way that the $\mathrm{O}_{2}$ grades were lower than the value found in atmospheric air. This was obtained considering the air as a mixture of $\mathrm{N}_{2}$ and $\mathrm{O}_{2}$, where there was a greater volumetric proportion in favor to $\mathrm{N}_{2}$. These studies are mentioned below.

Glassman and Yaccarino ${ }^{36}$ studied the influence of the variation in the $\mathrm{O}_{2}$ concentration of the oxidant for the formation of soot in ethene flames. The used $\mathrm{O}_{2}$ grades were about 9 and 50\% (molar fraction). The authors verified that the tendency for soot formation was a minimum of $c a .24 \%$. For grades lower than $24 \%$, the decrease in the $\mathrm{O}_{2}$ grade would increase the tendency for soot formation. While for grades higher than $24 \%$, the decrease would reduce the tendency. This is explained through the competition between the fuel pyrolysis rate and the oxidant of the soot in the domain of the process.

Du et al..$^{32}$ examined the effect of $\mathrm{O}_{2}$ concentration in the oxidant on the formation of soot in propane and ethene flames. The authors concluded that there was an increase in soot concentration with the variation of $\mathrm{O}_{2}$ concentration between 15 and $21 \%$, and this effect was due to the increase in temperature which occurred in this variation.

Goldstein et al..$^{42}$ verified the influence of the $\mathrm{O}_{2}$ grade of the oxidant in a partially premixed flame. The authors used a flame that was surrounded by atmospheric air, and it was involved through a $\mathrm{N}_{2}$ shield. It was verified that with the barrier of $\mathrm{N}_{2}$, soot formation in the flame was increased; a fact that was explained through the lack of $\mathrm{O}_{2}$ available to intensify the oxidation process.

Beltrame et al..$^{43}$ examined the influence of the air enrichment with oxygen in flames in the methane counterflow. The authors found that an increase in oxygen in the oxidant increased the soot formation. The oxidizer stream with oxygen content varied from 21 to $100 \%$.

Bertran et al. ${ }^{44}$ studied the soot formation in $\mathrm{C}_{2} \mathrm{H}_{2} / \mathrm{O}_{2}$ flames at different $\mathrm{C} / \mathrm{O}$ ratios in a closed chamber. The evolution temporal behavior and the volume fraction of soot particles were determined by laser extinction.
Wang et $a l .{ }^{41}$ noticed that there is an increase in the formation and oxidation of soot with OEC use caused basically by an increase in flame temperature. They also found that radiation caused by soot modifies the structure of the flame; it diminishes its temperature and reduces the emission of $\mathrm{NO}_{\mathrm{x}}$ substantially, especially in the zone of the flame top.

Mungekar and Atreya ${ }^{45}$ studied the interaction between oxygen addition on the methane stream, soot formation and thermal radiation in premixed counterflow flames. The authors found results in this configuration that showed enhancement of radiation heat transfer and soot formation. This is enhanced with further $\mathrm{O}_{2}$ addition.

Kumfer et al. ${ }^{46}$ evaluated the soot inception in OEC laminar coflow flames. The results suggested that soot inception occurs when the local $\mathrm{C} / \mathrm{O}$ ratio is above the critical value. In addition, results of fluorescence measurement of PAH (PAH were soot particles precursors) have shown that peaks of PAH concentration were in critical $\mathrm{C} / \mathrm{O}$ regions, confirming the trend of soot inception starting in $\mathrm{C} / \mathrm{O}$ ratios above the critical value.

Ergut et al. ${ }^{47}$ carried out a study regarding the evolution of products from incomplete combustion (PIC) emitted by ethylbenzene laminar flames, in order to identify the role of the equivalence ratio in the evolution of PAH and other PIC as soot precursors. In order to achieve their objectives, they have measured the temperatures and collected samples at various heights above the burner, and samples were analyzed for soot, PAH, oxygenated species, fixed gases and light hydrocarbons. The results indicated that the beginning of soot formation is not a function of the flame temperature alone, but also depends on the equivalence ratio. Nevertheless, additional development will be necessary to improve the predictive capability of the model used.

Kumfer et al. ${ }^{48}$ studied the combination of OEC and fuel dilution for ethylene diffusion flames, which results in increasing the stoichiometric mixture fraction, Zst. The authors varied Zst in order to verify the soot inception in normal and inverse coflow flames. The results have shown that when the Zst was increased, the soot formation was reduced or eliminated. The soot inception region is shown to be limited between a low-temperature and a high-temperature boundary. When the Zst increases, it moves these boundaries towards each other, resulting in an infinitely thin zone where the sooting limit is reached. These results thus suggest that soot formation is reduced when OEC is used in association with fuel dilution.

Ferrières et al. ${ }^{49}$ made experimental and computational studies of the oxidation of laminar premixed natural gas flames with variable mole fractions of hydrogen $(0,20$ and $60 \%$ ) present in the fuel mixture. The flames were 
operated at low pressure $(0.079 \mathrm{~atm})$ and during the tests the equivalence ratios were varied over a wide range $(0.74<\Phi<1.0)$, with constant cold gas velocity. At the same global equivalence ratio, the replacement of natural gas with $20 \%$ of $\mathrm{H}_{2}$ caused no significant effect, the small differences being due to a decrease in the amount of initial carbon. However, the results have suggested that in the $60 \%$ $\mathrm{H}_{2}$ flame the reduction in the formation of hydrocarbon species was more accentuated than in the $20 \% \mathrm{H}_{2}$ flame, and this can become a possible form to control the formation of hydrocarbon species, which are soot precursors.

Santos et al. ${ }^{50}$ studied the influence of oxygen enrichment of combustion air in diffuse acetylene flames. The results suggest that the use in set of the variation of the $\mathrm{O}_{2}$ grade of the air speed can represent an useful tool to control soot as depending on the speed, and the used grade of $\mathrm{O}_{2}$ in soot formation can be implemented or not. The levels of enrichment with the use of $\mathrm{O}_{2}$ were from 2 to $4 \%$.

Evaluating the described aspects, control of soot formation can be an important factor for a more rational implementation of OEC. With this control, the transferred thermal radiation in heating processes can be monitored and the formation of $\mathrm{NO}_{x}$ controlled. This aspect can be a factor in the use of the technology, and its peculiarities require further research.

\section{Potential Problems on the OEC Use}

The potential problems for the OEC use are presented by Baukal Jr.: ${ }^{3}$ damage in heat-resistance caused by improper heat distribution, heating not uniform, instability in flames, increase in pollutant emission ( $\mathrm{NO}_{\mathrm{x}}$ in particular), increase in noise and possible backfiring (flashback) in premixed burners. The cost of oxygen (an economical analysis is necessary for the decision of OEC utilization) and the durability of the equipments due to the higher temperatures can be other problems to implementation of the OEC technology.

All these energy and environmental aspects need to be weighed up before taking a decision to implement OEC technology.

\section{Conclusions and Future Perspectives}

Most industrial combustion processes use atmospheric air as oxidant. However, many processes can be improved using a richer oxidant in the oxygen than combustion air obtained by injecting oxygen in the oxidant chain. This is the principle of combustion enriched with the oxygen which can promote increases in productivity and in thermal efficiency, lower volumes of combustion gases, among other benefits.

According to Greco, ${ }^{51}$ industries have to become increasingly competitive over time through a constant search for lower costs and greater productivity. OEC is an alternative that companies should not ignore. Further two factors are also important. First, the possibility of emissions reduction and second $\mathrm{OEC}$ offers increased profit possibilities and advantages.

Baukal Jr. ${ }^{3}$ concludes that lower $\mathrm{O}_{2}$ costs, connected to the environment and to the operation benefits of OEC, make this an attractive technology.

As demonstrated in this work, due to the greater energy efficiency, OEC should be considered by the oil industry and other industrial segments as an important technological advance to guarantee the energy efficiency, diminish fuel consumption and with this contribute to the reduction of emissions and global warming.

Energy and environmental aspects and the potential problems must be analyzed to introduce this technology. In this work, we have seen beneficial aspects which can help industries using heating processes to increase energy efficiency and to improve their emissions balance. These two aspects are already enough to initiate studies of the technical and economic feasibility for the use of the technology in oil and gas industries and its derivatives, industries which are great energy consumers and have a significant environmental impact, in particular associated to the greenhouse effect.

Research needs to be carried out into OEC use for performance improvement of burners, especially in oil and derivatives industries, the processes of heat transfer, basically for radiation heat process, and new technological applications for the process effectiveness improvement.

\section{Acknowledgements}

The authors are grateful to SENAI National Department (Brazil) and SENAI Cimatec for financial support.

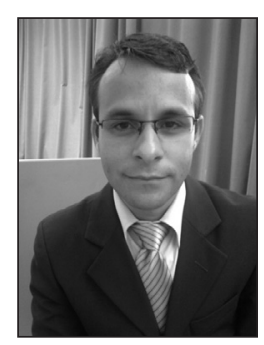

Alex A. B. Santos is engaged in a PhD program in Energy and Environment at Centro Interdisciplinar de Energia e Ambiente (CIEnAm) at the Universidade Federal da Bahia (UFBA, Bahia State, Brazil). He got his $B S c$ degree in Mechanical Engineering at the UFBA in 1998 and the MSc in Mechanical Engineering at the University of Campinas (UNICAMP, São Paulo State, Brazil) in 2001. He is currently an Assistant Professor at the Faculty of Technology of the 
Centro Integrado de Manufatura e Tecnologia (Cimatec SENAI, Bahia State, Brazil), where he guides master students in interdisciplinary programs. He develops research projects with the industrial sectors with focus on the technological innovation. He is also a Process Operational Manager at the Cimatec and a Senior Member of the Associação Brasileira de Engenharia e Ciências Mecânicas (ABCM). He has experience in Mechanical Engineering, on the following topics: formation and control of soot and NOx, industrial maintenance, energy, thermal systems, heat transfer, combustion, evaluation and optimization of industrial equipments.

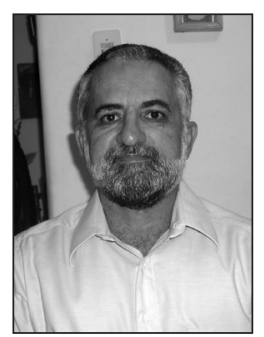

Ednildo A. Torres is the coordinator of the Laboratorio de Energia e Gás (LEN) of the Polytechnic School of the Universidade Federal da Bahia (UFBA, Bahia State, Brazil). He obtained his PhD in Energy at the University of Campinas (UNICAMP, São Paulo State, Brazil) and the MSc degree at the Polytechnic School of the University of São Paulo (USP, São Paulo State, Brazil) and graduated at the UFBA. He was the head of the Department of Chemical Engineering in the UFBA, with 30 years of experience in technological development between Industrial Research Centers and Universities. He is full member of the Academy of Sciences from the Bahia State. He supervised 21 MSc, $4 \mathrm{PhD}$ and ca. 50 undergraduate students. He published over 80 papers in conference proceedings, over 15 journal articles, 3 books, 5 chapters of books, texts in newspapers and magazines, has more than 10 technology products, in addition to several presentations at national and international conferences. He has agreements with national and international companies, such as Braskem, Monsanto, Griffin, Caraíba Metals, Petrobras-Petróleo Brasileiro, Politeno PetroBahia and Bahia Gas. He was member of an engineering company in year 1991 and has deposited three patents.

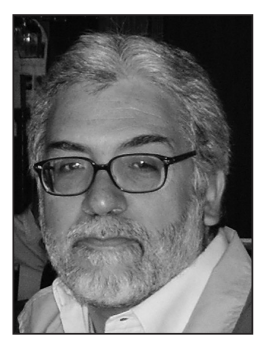

Pedro A. P. Pereira is graduated in Chemistry at the Universidade de Brasília (UnB, Federal District, Brazil) in 1977, specialized in Nuclear Technology (Universidade Federal de Minas Gerais, UFMG, Minas Gerais State, Brazil) in 1980. He obtained his MSc degree in Chemistry (Inorganic Analytical Chemistry) at the Pontificia Universidade Católica do Rio de Janeiro in 1986 and the PhD degree in Analytical Chemistry at the Institute of Chemistry at the Universidade Federal da Bahia (UFBA, Bahia State, Brazil) in 1997 and the post-doctorate at the University of California (UCLA, California State, USA). He is currently an Associate Professor at UFBA. He has experience in the areas of Environmental and Analytical Chemistry, with emphasis on chromatography, couplings solid-phase microextraction-gas chromatography-mass spectrometry (SPME GC-MS) and liquid chromatography-mass spectrometry (LC-MS), mainly in the following topics: volatile organic compounds (VOCs), polycyclic aromatic hydrocarbons (PAHs), carbonyl compounds, airborne particulate matter, nano aerosols, pesticides and foods.

\section{References}

1. Turns, S. R.; An Introduction to Combustion, Concepts and Applications, $1^{\text {st }}$ ed., McGraw-Hill Int. Editions: Singapore, 1996.

2. Energy Research Company; Brazilian Energy Balance (EPE), Ministry of Mines and Energy: Brasília, 2009. http://www. mme.gov.br/mme/galerias/arquivos/publicacoes/BEN/8_-_ Edicoes_Anteriores_BEN_e_Resenhas_-_pdf/1_-_BEN_ Anteriores/6_-_BEN_2009_xrelatxrio_completox.pdf.

3. Baukal Jr., C. E.; Oxygen-Enhanced Combustion, $1^{\text {st }}$ ed., CRC Press: New York, 1998.

4. Williams, S. J.; Cuervo, L. A.; Chapman, M. A.; Report GRI89/0256, Gas Research Institute: Chicago, 1989

5. Baukal, C. E.; Gebhart, B.; Int. J. Heat Mass Transfer 1997, 40, 2539.

6. Takita, K.; Combust. Flame 2002, 128, 301.

7. Murphy, J. J.; Shaddix, C. R.; Combust. Flame 2006, 144, 710.

8. Boushaki, T.; Sautet, J.-C.; Labegorre, B.; Combust. Flame 2009, 156, 2043.

9. López, J. G; Martínez, M.; Millera, A.; Bilbao, R.; Alzueta, M. U.; Combust. Flame 2011, 158, 48.

10. Smart, J. P.; Patel, R.; Riley, G. S.; Combust. Flame 2010, 157, 2230.

11. Chen, R.; Axelbaum, R. L.; Combust. Flame 2005, 142, 62.

12. Sunderland, P. B.; Krishnan, S. S.; Gore, J. P.; Combust. Flame 2004, 136, 254.

13. Skeen, S. A.; Yablonsky, G.; Axelbaum, R. L.; Combust. Flame 2009, 156, 2145.

14. Skeen, S. A.; Yablonsky, G.; Axelbaum, R. L.; Combust. Flame 2010, 157, 1745.

15. Han, J.-H.; Lee, C.-E.; Kum, S.-M.; Hwang, Y.-S.; Energy Fuels 2007, 21, 3202.

16. Cao, H.; Sun, S.; Liu, Y.; Wall, T. F.; Energy Fuels 2010, 24, 131.

17. Andersson, K.; Johansson, R.; Johnsson, F.; Leckner, B.; Energy Fuels 2008, 22, 1535.

18. Lacava, P. T.; Carvalho Jr., J. A.; Pimenta, A. P.; Ferreira, M. A.; Energy 2006, 31, 528. 
19. Bussman, W. R.; Baukal, C. E.; Energy 2009, 34, 1624.

20. Cho, C. P.; Kim, H. Y.; Yoon, S. S.; Combust. Flame 2009, 156, 14.

21. Santos, A. A. B.; Torres, E. A.; Pereira, P. A. P.; Twenty-Third International Conference on Efficiency, Cost, Optimization Simulation and Environmental Impact of Energy Systems, 2010, 638-1032-1.

22. Santos, A. A. B.; Torres, E. A.; Pereira, P. A. P.; Twenty-Second International Conference on Efficiency, Cost, Optimization Simulation and Environmental Impact of Energy Systems, 2009, R30340B.

23. Strauss, W. S.; Lukens, J. A.; Young, F. K.; Bingham, F. B.; $13^{\text {th }}$ National Waste Processing Conference, 1998, 315.

24. Farrell, L. M.; Pavlack, T. T.; Selines, R. J.; Rich, L.; Steel Times 1996, 224, 259.

25. Glassman, I.; Combustion, $2^{\text {nd }}$ ed., Academic Press Inc.: Orlando, 1987.

26. Smith, O. I.; Prog. Energy Combust. Sci. 1981, 7, 275.

27. Brookes, S. J.; Moss, J. B.; Combust. Flame 1999, 116, 486.

28. Saito K.; Williams, F. A.; Gordon A. S.; Combust. Sci. Technol. 1986, 47, 138.

29. Gülder, O. L.; Combust. Flame 1995, 101, 302.

30. Wey, C.; Int. Soc. Opt. Eng. 1994, 2122, 94.

31. Hura, H. S.; Glassman, L.; Proc. Combust. Inst. 1988, 22, 371.

32. Du, D. X.; Axelbaum, R. L.; Law, C. K.; Twenty-Third Symposium on Combustion, 1990, 1501.

33. Leung, K. M. ; Lindstedt, R. P.; Combust. Flame 1991, 87, 289.

34. Hwang, J. Y. ; Chung, S. H.; Lee, W.; Proc. Combust. Inst. 1998, 27, 1531.

35. Kent, J. H.; Bastin, S. J.; Combust. Flame 1984, 56, 29.

36. Glassman, I.; Yaccarino, P.; Combust. Sci. Technol. 1980, 24, 107.
37. Lee, K. O.; Megaridis, C. M.; Zelepouga, S.; Saveliev, A. V.; Kennedy, L. A.; Charon, O.; Ammouri, F.; Combust. Flame 2000, 121, 323.

38. Zelepouga, S. A.; Saveliev, A. V.; Kennedy, L. A.; Fridman, A. A.; Combust. Flame 2000, 122, 76.

39. Hwang, S. S.; Gore, J. P.; J. Power Energy 2002, 216, 379.

40. Wang, L.; Endrud, N. E.; Turns, S. R.; D’Agostini, M. D.; Slavejkov, A. G.; Combust. Sci. Technol. 2002, 174, 45.

41. Wang, L.; Haworth, D. C.; Turns, S. R.; Modest, M. F.; Combust. Flame 2005, 141, 170.

42. Goldstein Jr., L.; Fassani, F. L.; Santos, A. A. B.; Ferrari, C. A.; Int. Comm. Heat Mass Transfer 2002, 29, 223.

43. Beltrame, A.; Porsnev, P.; Merchan-Merchan, W.; Saveliev, A.; Fridman, A.; Kennedy, L. A.; Petrova, O.; Zhdanok, S.; Amouri, F.; Charon, O.; Combust. Flame 2001, 124, 295.

44. Bertran, C. A.; Marques, C. S. T.; Benvenutti, L. H.; J. Braz. Chem. Soc. 2002, 13, 47.

45. Mungerkar, H. P.; Atreya, A; ASME J. Heat Transfer 2006, 128, 361.

46. Kumfer, B. M., Skeen, S. A.; Chen, R.; Axelbaum, R. L.; Combust. Flame 2006, 147, 233.

47. Ergut, A.; Levendis, Y. A.; Richter, H.; Howard, J. B.; Carlson, J.; Combust. Flame 2007, 151, 173.

48. Kumfer, B. M.; Skeen, S. A.; Axelbaum, R. L.; Combust. Flame 2008, 154, 546.

49. Ferrières, S.; Bakali, A. E.; Lefort, B.; Montero, M.; Pauwels, J. F.; Combust. Flame 2008, 154, 601.

50. Santos, A. A. B.; Goldstein Jr., L.; Ferrari, C. A.; Int. Comm. Heat Mass Transfer 2009, 36, 445.

51. Greco, C.; Informativo C. Greco 1999, 6 (ano II), 1.

Submitted: January 15, 2011

Published online: August 11, 2011 